\title{
Structure Equation Model for the Successful Implementation of ICT / Automation in Construction Project Management in India
}

\author{
Saurav Dixit ${ }^{1}$, Priyanka Singh ${ }^{2}$ and Krystyna Araszkiewicz ${ }^{3}$
}

1 RICS School of Built Environment, Amity University, Noida, India, sauravarambol@gmail.com

2 Department of Civil Engineering, Amity School of Engineering \& Technology, Amity University Noida, Uttar

Pradesh, India

3 West Pomeranian University of Technology, Szczecin, Poland

\begin{abstract}
Each project is unique in nature and has its own complexities associated with it, and the management of construction projects requires effective and well-organized communication between all parties and stakeholders involved in the project. Coordination and collaboration between all stakeholders are the key to the success of any project. This is the sole importance among the team members of completing any given project on time and at the required cost. ICT is a technology that can be used to enhance communication between all the parties concerned working on specific or concerned projects, including stakeholders, etc. IT-based technology has many tools and software that have the tremendous ability to ease work related to the flow of information, data collection and storage, etc. The objective of current research is to identify and analyze the factors affecting the implementation of ICT / Automation in construction projects in India using structured equation modelling (SEM). The literature review has been carried out and some attributes have been identified regarding the benefits, barriers and enablers of ICT. These attributes were included in the questionnaire prepared to receive a response from industry professionals in the construction sector. The survey was conducted in the Indian construction industry and the response of various industry professionals from top-level management and middle-level management was recorded. The data collection was carried out and the response was further analyzed. Various factors affecting the use of ICT in construction project management have been analyzed using different statistical techniques (exploratory factor analysis, reliability analysis and structure equation model). The findings of the research provided a SEM model for the successful implementation of ICT in construction projects.
\end{abstract}

(c) 2020 The Authors. Published by Budapest University of Technology and Economics \& Diamond Congress Ltd Peer-review under responsibility of the Scientific Committee of the Creative Construction Conference 2020.

Keywords: ICT, automation in construction, construction management, project management, structure equation model

\section{Introduction}

Many building aspects reflect the significant benefits that the industry could reap from information and digital technologies: the vast quantities of knowledge to be handled, production focus and participant dissemination. Nonetheless, IT adoption in construction sector usually considered minimal and potential adoption predictions have proven optimistic (Fukao, Ikeuchi, Kim, \& Kwon, 2016; Suryawanshi \& Narkhede, 2015). While more champions were disappointed, the use of digital technology in construction has increased. The use of information and communication technology (ICT), also known as information technology (IT) has grown enormously in such areas as design and planning, cost control and budgeting, computer-aided facilities management, among others, thereby creating many opportunities for better and more efficient project execution within the industry. This study has the potential to offer some new insights 
into ICT in the construction and context creation. The explanation is, because in developing economies such as India, what a company may see as major challenges in implementing and using ICT would be significantly different from those in a developed economy such as UK where the ICT Industry with various regulatory frameworks and cultural constraints (Jayasudha \& Vidivelli, 2016; Kenley, 2014; Koseoglu \& Nurtan-Gunes, 2018).

\subsection{Objectives of the study}

The objective of current research is to identify and analyze the factors affecting the implementation of ICT / Automation in construction projects in India using structured equation modelling (SEM).

\section{Literature review}

The use of information communication and technology is simple to handle different resources, including human resources. New techniques, such as BIM (Building Information Modelling), have totally changed the architectural point of view of the global market. The Internet is used internationally, and the projects are debated in several ways (Arayici et al., 2011). (Gu \& London, 2010) has stated that there is a lack of education of these technologies and professionals in construction industry find it difficult to use and learn these technologies. The ICT based technology can only be adopted in construction sector if these technologies are adopted by large and big name organizations of a nation and set a benchmark for other organizations. The lack of efforts made by these organizations are a big barrier in the adoption of ICT. The awareness of technology and user education is required in the industry to improve the acceptance and adoption of ICT. The top management should be aware of these technologies and should adopt and promote so that everybody at middle and lower management takes it seriously (Arnold, Javernick-will, \& Asce, 2013; Kang, Brien, \& Mulva, 2013; Son, Lee, \& Kim, 2015). The quality of tools or ICT equipment made available to the construction companies are also one of the barriers. During the use of these technologies some organization are also not convinced regarding the security these software or tools provide [3]. The use on building project performance has been recently evaluated through best practice and the direct impact on the project cost growth of use of 3D CAD, which means the cost outcome has a negative impact as the associations of project output and technological use at project and process level. The results indicate that the link between the technical usage and the project findings has been explored and that the cost and the timeline of the project will be greatly influenced by the data / intensive data / knowledge and management functions. The IT utilization enhances time-bound productivity and has a relatively low cost-effective impact (Dixit, Mandal, Thanikal, \& Saurabh, 2019; Dixit, Sharma, \& Singh, 2020; Dixit \& Sharma, 2020)

\section{Research methodology and data analysis}

The research methodology used in the analysis is the compilation of primary data for ICT adoption in the Indian building industry. For data collection, a standardized questionnaire survey is used. The study targets are consultants, clients, investors, contractors, government officials, architects and other key players in the Indian construction market. The Likert five-point scale is used to identify respondents where one has the least impact and five has the greatest effect. The survey was conducted in the Indian construction industry and the response of various industry professionals from top-level management and middle-level management was recorded. The data collection was carried out and the response was further analyzed. Various factors affecting the use of ICT in construction project management have been analyzed using different statistical techniques fig. 1 and 2. Approximately 350 questionnaires were circulated and 88 correct answers were returned (Dixit et al., 2020; Shah et al., 2019). 


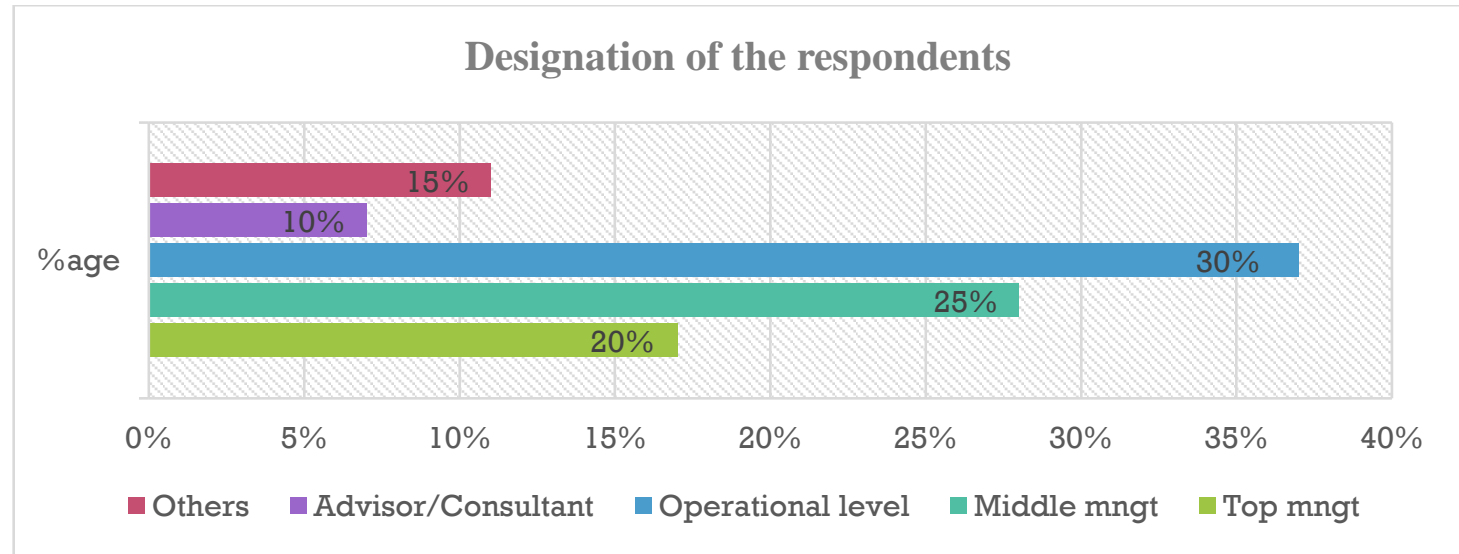

Figure 1. Position/Designation of the respondents

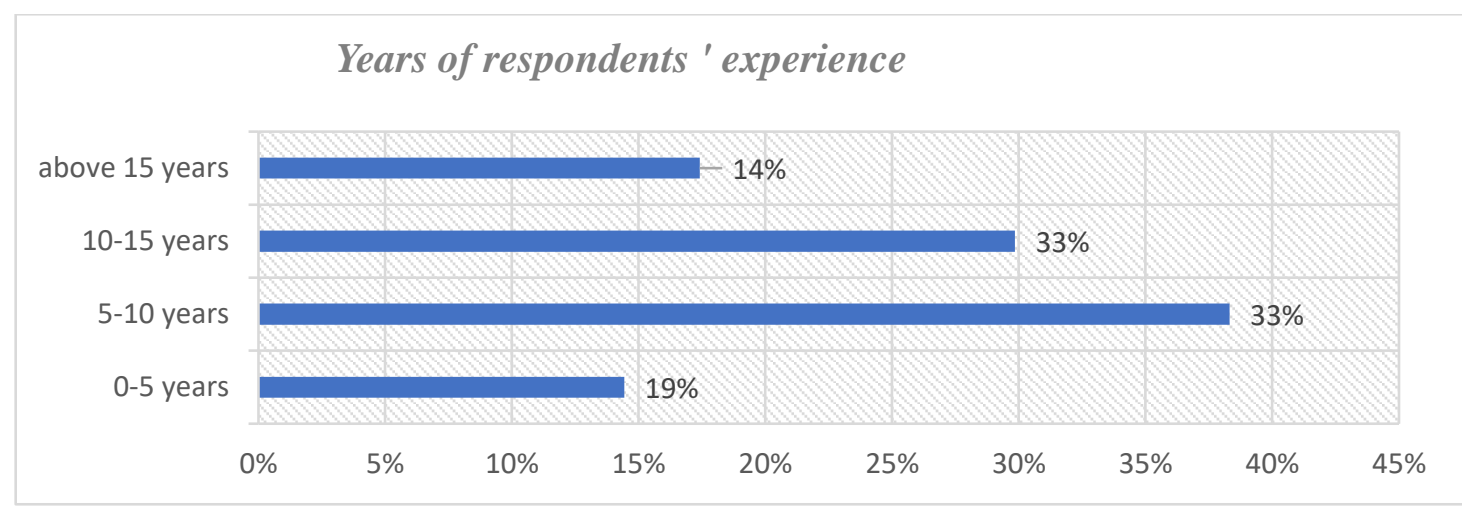

Figure 2. Years of respondents ' experience

\subsection{Reliability analysis}

Reliability refers to the degree to which a calculation provides accurate outcomes if measurements are replicated many times. The reliability analysis is called the reliability analysis. Reliability analysis is calculated by obtaining the ratio of the systemic variability by calculation of the correlation of the scores obtained from different administrations of the scale table 1. And, if the reliability measurement correlation is strong, the scale findings are consistent and therefore accurate (Hartmann, Meerveld, Vossebeld, \& Adriaanse, 2012).

Table 1. Reliability analysis/Cronbach's alpha for different factors

\begin{tabular}{lll}
\hline Factors & Cronbach's Alpha & No. of attributes \\
\hline Factor 1 (Site management) & 0.82 & 06 \\
Factor 2 (Leadership management) & 0.81 & 05 \\
Factor 3 (Project change management) & 0.84 & 02 \\
Factor 4 (Performance) & 0.87 & 02 \\
\hline
\end{tabular}

\subsection{Exploratory factor analysis}

Exploratory factor analysis is a statistical method used to decrease data to a smaller collection of summary variables and to investigate the theoretical framework underlying the phenomenon. The EFA has reduced the 19 attributes into 4 factors. All of the selected attributes have a factor load of more than 0.4. The cumulative quantity of variance explained by four factors are $57.25 \%$ which is above the minimum threshold (above 50\%). All four factors from the EFA were shown in Table 2 below. 
Proceedings of the Creative Construction e-Conference (2020) 008

Available online at e-2020.creative-construction-conference.com/proceedings/

Table 2. EFA table

\begin{tabular}{lll}
\hline Attribute/variable name & Factor loading & \%age of variance explained \\
\hline Site management & & $21 \%$ \\
Less handling and managing charges & 0.6 & \\
Helps to improve collaborations and coordination & 0.8 & \\
Improve swift communication & 0.8 & \\
concurrent construction management & 0.6 & \\
Efficient procurement of materials & 0.8 & \\
Helps in contract management & 0.6 & \multirow{2}{*}{$14.50 \%$} \\
Leadership management & & \\
Metadata information availability to the management & 0.4 & \\
Efficient query resolution mechanism & 0.5 & \\
Project change management & & \\
Streamline flow of accurate information & 0.5 & \\
Project information is stored precisely in a better way & 0.7 & \\
ICT refines the productivity of organization & & $9.45 \%$ \\
Real time project information availability & 0.6 & \\
Effective project change management & 0.6 & \\
Performance & 0.4 & \\
On time completion of project & & \\
Within budget completion of the project & & \\
\hline
\end{tabular}

\subsection{Structure Equation Modelling (SEM)}

Structural Equation Modeling involves a number of mathematical models, computer algorithms and computational methods that are suitable for networks of data structures. SEM contains confirmatory factor analysis and composite confirmatory analyzes, path analysis and partly least square path modeling and latent growth modeling. Models of structural equation are also used to test 'latent' structures that can not be observed. The use of SEM in social sciences is generally justified because the relationship between unknown structures (latent variables) is defined by observed variables. The review of literature and CFA grouped the 19 attributes into 4 main significant factors are: Site Management (SM), Project change management (PCM), Leadership management (LM), And Performance (PR) of construction projects the following hypothesis are formed (refer conceptual model) fig. 3:

- Site management (SM) factors are having a significant impact on performance (PR) of construction projects

- Project change management (PCM) having a significant impact over productivity (PR) of construction projects.

- Leadership management (LM) is having a significant impact on productivity (PR) of construction projects.

\subsection{Findings of the study}

The findings of the SEM results concludes that the most significant factor impacts the performance of the construction projects is site management (SM) (Abbott, 2013; Allen, 2016; Bröchner \& Olofsson, 2012; Rivas, Borcherding, González, \& Alarcón, 2011) followed by Project Project change management (PCM) and Leadership management having a significant value of $0.03,0.05$, and 0.01 respectively (table 3 and 4). 


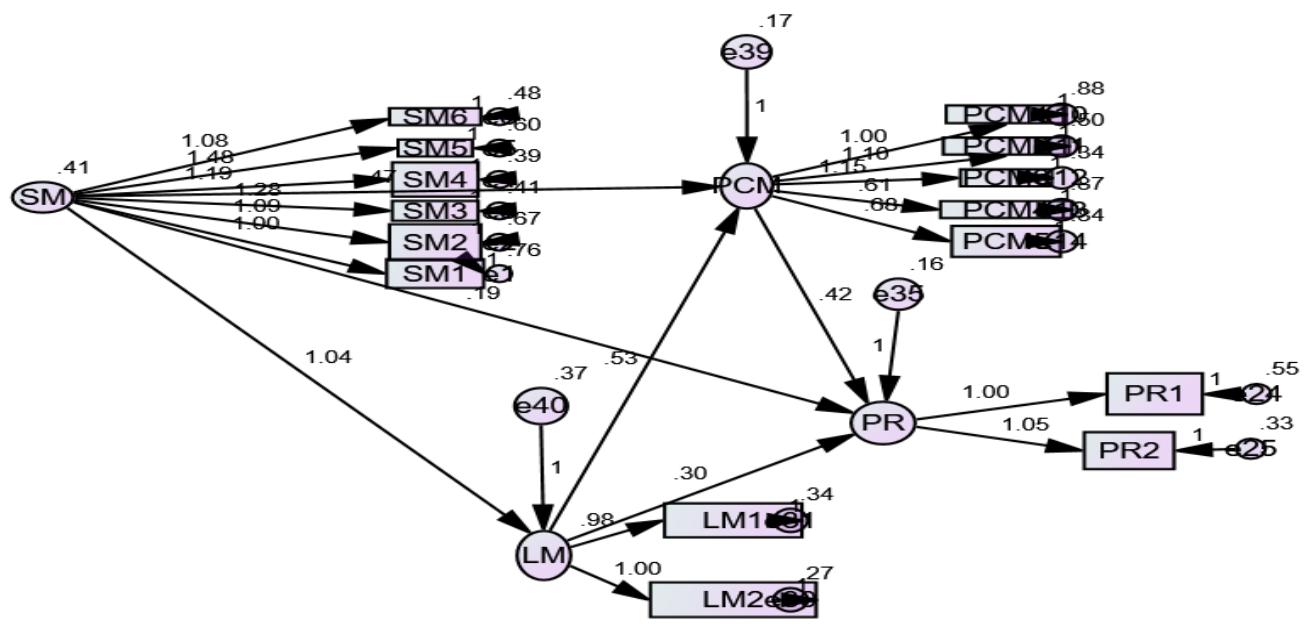

Figure 3. SEM model

Table 3. Measure for the goodness of fit (GOF)

\begin{tabular}{lll}
\hline Measure for the goodness of fit (GOF) & Initial model values & Final model values \\
\hline$X^{2} / \mathrm{DOF}$ & 3.25 & 1.98 \\
Comparative fit index (CFI) & 0.62 & 0.85 \\
Goodness of fit index (GFI) & 0.58 & 0.84 \\
Tucker-Lewis Index (TLI) & 0.61 & 0.94 \\
Root mean square error of approx. (RMSEA) & 0.13 & 0.09 \\
Incremental fit index (IFI) & 0.65 & 0.79 \\
Normal fit index (NFI) & 0.73 & 0.80 \\
\hline
\end{tabular}

Table 4. Hypothetical path and their influences

\begin{tabular}{llll}
\hline Hypothetical path and their influences & Path coefficient & Sig. $(p)$ & Interpretation \\
\hline $\mathrm{H} 1: \mathrm{PR} \leftarrow \mathrm{PCM}$ (expected -ve impact) & 0.42 & 0.05 & Accepted \\
$\mathrm{H} 2: \mathrm{PR} \leftarrow \mathrm{LM}$ (expected +ve impact) & 0.30 & 0.01 & Accepted \\
$\mathrm{H} 3: \mathrm{PR} \leftarrow \mathrm{SM}$ (expected +ve impact) & 0.53 & 0.03 & Accepted \\
\hline
\end{tabular}




\section{Discussion and conclusion}

The progress of any project depends on good communication and understanding between all project participants and stakeholders. Good communication is the secret to the success of any project. In the construction sector, projects need very good communication management between all parties which can be accomplished through the adoption of ICT or ICT technology. The study identifies various attributes affecting the adoption of ICT in the Indian built environment. Large organizations and policy agencies have to take care of that, and guidance and regulations are needed to make the best use of these technologies, which definitely will help other professionals, our services, our organizations and companies. In order to compete world-wide and to aspire to be an established construction industry and nation in the eyes of the global world (Aguilar \& Hewage, 2013; Forcada, Fuertes, Gangolells, Casals, \& Macarulla, 2013; Kim, Park, Lim, \& Kim, 2013; Zeng, 2020), the industry will have to accept change and with the new age we will welcome these optimistic changes with open hands. In this regard, the governments and big corporations in our industry need definite help, so that small businesses can see them as a model and follow their footsteps (Fadiya, Georgakis, \& Chinyio, 2015; Ikediashi, 2014).

\section{Acknowledgements}

The authors would like to thanks to the participants who have provided the data for the study and shred their valuable feedback for the study. The authors also like to acknowledge the both the affiliations for providing the resources and support during the research work.

\section{References}

[1] Abbott, M. (2013). A Comparative Approach to Determining the Growth of Productivity of the New Zealand Construction Industry. Australasian Journal of Construction Economics and Building, 13(4), 65-77.

[2] Aguilar, G. E., \& Hewage, K. N. (2013). Automation in Construction. Automation in Construction, 35, 217-228. https://doi.org/10.1016/j.autcon.2013.05.007

[3] Ahuja, V., Yang, J., \& Shankar, R. (2009). Benefits of collaborative ICT adoption for building project management. 9(3), 323-340. https://doi.org/10.1108/14714170910973529

[4] Allen, S. G. (2016). Why Construction Industry Productivity Is Declining Author (s): Steven G. Allen Source: The Review of Economics and Statistics, Vol .67, No . 4 (Nov ., 1985), pp . 661-669 Published by: The MIT Press Stable URL: http://www.jstor.org/stable/1924. 67(4), 661-669.

[5] Arayici, Y., Coates, P., Koskela, L., Kagioglou, M., Usher, C., \& Reilly, K. O. (2011). Automation in Construction Technology adoption in the BIM implementation for lean architectural practice. Automation in Construction, 20(2), 189-195. https://doi.org/10.1016/j.autcon.2010.09.016

[6] Arnold, P., Javernick-will, A., \& Asce, A. M. (2013). Projectwide Access : Key to Effective Implementation of Construction Project Management Software Systems. (May), 510-518. https://doi.org/10.1061/(ASCE)CO.1943-7862.0000596

[7] Bröchner, J., \& Olofsson, T. (2012). Construction Productivity Measures for Innovation Projects. Journal of Construction Engineering and Management, 138(5), 670-677. https://doi.org/10.1061/(ASCE)CO.1943-7862.0000481

[8] Dixit, S., Mandal, S. N., Thanikal, J. V, \& Saurabh, K. (2019). Study of Significant Factors Affecting Construction Productivity Using Relative Importance Index in Indian Construction Industry. 09010.

[9] Dixit, S., \& Sharma, K. (2020). An Empirical Study of Major Factors Affecting Productivity of Construction Projects. In K. G. Babu, H. S. Rao, \& Y. Amarnath (Eds.), Emerging Trends in Civil Engineering (pp. 121-129). Singapore: Springer Singapore.

[10] Dixit, S., Sharma, K., \& Singh, S. (2020). Identifying and Analysing Key Factors Associated with Risks in Construction Projects. In K. G. Babu, H. S. Rao, \& Y. Amarnath (Eds.), Emerging Trends in Civil Engineering (pp. 25-32). Singapore: Springer Singapore.

[11] Fadiya, O., Georgakis, P., \& Chinyio, E. (2015). Decision-making framework for selecting ICT-based construction logistics systems. https://doi.org/10.1108/JEDT-07-2011-0047

[12] Forcada, N., Fuertes, A., Gangolells, M., Casals, M., \& Macarulla, M. (2013). Automation in Construction Knowledge management perceptions in construction and design companies. Automation in Construction, 29, 83-91. https://doi.org/10.1016/j.autcon.2012.09.001

[13] Fukao, K., Ikeuchi, K., Kim, Y., \& Kwon, H. U. (2016). Why was Japan left behind in the ICT revolution? Telecommunications Policy, 40(5), 432-449. https://doi.org/10.1016/j.telpol.2016.01.008

[14] Gu, N., \& London, K. (2010). Automation in Construction Understanding and facilitating BIM adoption in the AEC industry. Automation in Construction, 19(8), 988-999. https://doi.org/10.1016/j.autcon.2010.09.002

[15] Hartmann, T., Meerveld, H. Van, Vossebeld, N., \& Adriaanse, A. (2012). Automation in Construction Aligning building information model tools and construction management methods. Automation in Construction, 22, 605-613. https://doi.org/10.1016/j.autcon.2011.12.011

[16] Ibem, E. O., \& Laryea, S. (2014). Automation in Construction Survey of digital technologies in procurement of construction projects. Automation in Construction, 46, 11-21. https://doi.org/10.1016/j.autcon.2014.07.003

[17] Ikediashi, D. I. (2014). Assessing the use of ICT systems and their impact on construction project performance in the Nigerian construction industry. https://doi.org/10.1108/JEDT-08-2014-0047

[18] Jayasudha, K., \& Vidivelli, B. (2016). Analysis of major risks in construction projects. ARPN Journal of Engineering and Applied Sciences, 11(11), 6943-6950.

[19] Kang, Y., Brien, W. J. O., \& Mulva, S. P. (2013). Automation in Construction Value of IT : Indirect impact of IT on construction project performance via Best Practices. Automation in Construction, 35, 383-396. https://doi.org/10.1016/j.autcon.2013.05.011

[20] Kenley, R. (2014). Productivity improvement in the construction process. Construction Management and Economics, 32(6), 489-494. https://doi.org/10.1080/01446193.2014.930500 
Proceedings of the Creative Construction e-Conference (2020) 008

Available online at e-2020.creative-construction-conference.com/proceedings/

[21] Kim, C., Park, T., Lim, H., \& Kim, H. (2013). Automation in Construction On-site construction management using mobile computing technology. Automation in Construction, 35, 415-423. https://doi.org/10.1016/j.autcon.2013.05.027

[22] Koseoglu, O., \& Nurtan-Gunes, E. T. (2018). Mobile BIM implementation and lean interaction on construction site: A case study of a complex airport project. Engineering, Construction and Architectural Management, 25(10), 1298-1321. https://doi.org/10.1108/ECAM-08-2017-0188

[23] Rivas, R. a., Borcherding, J. D., González, V., \& Alarcón, L. F. (2011). Analysis of Factors Influencing Productivity Using Craftsmen Questionnaires: Case Study in a Chilean Construction Company. Journal of Construction Engineering and Management, 137(4), 312320. https://doi.org/10.1061/(ASCE)CO.1943-7862.0000274

[24] Samuelson, O., \& Björk, B. (2014). Automation in Construction A longitudinal study of the adoption of IT technology in the Swedish building sector. Automation in Construction, 37, 182-190. https://doi.org/10.1016/j.autcon.2013.10.006

[25] Shah, M. N., Dixit, S., Kumar, R., Jain, R., \& Anand, K. (2019). Causes of delays in slum reconstruction projects in India. International Journal of Construction Management, 1-16. https://doi.org/10.1080/15623599.2018.1560546

[26] Son, H., Lee, S., \& Kim, C. (2015). Automation in Construction What drives the adoption of building information modeling in design organizations ? An empirical investigation of the antecedents affecting architects ' behavioral intentions. Automation in Construction, 49, 92-99. https://doi.org/10.1016/j.autcon.2014.10.012

[27] Suryawanshi, K., \& Narkhede, S. (2015). Green ICT for Sustainable Development: A Higher Education Perspective. Procedia Computer Science, 70, 701-707. https://doi.org/10.1016/j.procs.2015.10.107

[28] Zeng, W. (2020). Smart construction site in mega construction projects : A case study on island tunneling project of Hong KongZhuhai- Macao Bridge. (March 2018). https://doi.org/10.15302/J-FEM-2018075 